\title{
Vertical and Horizontal Approaches to Kinship and Ways of Doing Anthropological Fieldwork in Siberia ${ }^{1}$
}

\author{
Csaba Mészáros \\ Institute of Ethnology, RCH, Hungarian Academy of Sciences, Budapest
}

\begin{abstract}
The study of kinship has occupied a central role in anthropological scholarships for more than a hundred years. In the 1970s, after the deconstruction of kinship as the inherent logic of social structure, studies on kinship faced a number of new epistemological issues. Based on experiences gained during subsequent fieldworks in Yakutia, the author tackles a few of them in this article. Due to the legacy of Soviet-type ethnography in Yakutia, people even in the remotest villages usually have a firm idea of what anthropological fieldwork is about. Reflecting on his fieldwork strategies in Yakutia while studying local kin relations, the author argues that anthropologists should not neglect to consider the expectations local communities have of the goals and means of the fieldwork. In the case of kinship research in Yakutia, local communities are interested in reconstructing the vertical aspects of kin relations instead of unfolding horizontal relations for the anthropologist.
\end{abstract}

Keywords: Kinship, Siberia, fieldwork methods, genealogy, lineage theory

\section{PARALLEL APPROACHES DURING FIELDWORK}

The rich tradition of kinship studies that was prevalent for almost 100 years (1870-1960), ${ }^{2}$ based on the study of descent and marriage, as well as other social relations that were interpreted along the same lines, have long been at the center of anthropological investigations and heavily influenced the research methodology of field studies. In terms of its historical significance, kinship is not just one of many anthropological research topics, but rather an area of knowledge that made other topics and cultural and social phenomena easily accessible to researchers, partly due to the methodology of anthropological fieldwork. However, owing to the turn brought on by the first long-

\footnotetext{
${ }^{1}$ The study was sponsored by the János Bolyai research grant of the Hungarian Academy of Sciences.

${ }^{2}$ These one hundred years are delimited by the research tradition that extends from Morgan's questionnaire on kinship to the exploration of the previously little-researched mountain communities of Papua New Guinea.
} 
term fieldworks in the New Guinea highlands ${ }^{3}$ and the kinship studies of interpretive anthropology, ${ }^{4}$ the relevance of kinship research greatly diminished in the second half of the twentieth century, and it was also called into question whether the category of kinship can serve as a key to understanding the totality of a community's culture (PATTERSON 2005:12).

As a result of this turn, it became questionable whether kinship can even be considered a comprehensive human universal at all (SCHNEIDER 1969). Indeed, everything anthropologists thought of kinship became problematic, and it became apparent that in many cases ideas about the nature of kinship cultivated by anthropological scholarship obscured, rather than elucidated, indigenous ideas and practices (SCHNEIDER 1984:193). That is, some of the kinship phenomena that were radically different from European systems could not actually appear in anthropological discourses.

As a corollary, the examination of the question of how independent cultural systems within certain communities control the social phenomenon of kinship and regulate interpersonal behavior has increasingly determined the direction of anthropological interest. However, this interest in focusing on the description and understanding of native ideas (as independent cultural systems) and practices of kinship usually aimed at contrasting exotic examples with the cultural system of kinship as understood and practiced in Western societies (Goodale 1971; Marshall 1976). The essentialism inherent in this research focus and line of questioning - emphasizing the discreteness and uniqueness of cultures ${ }^{5}$ - amplified and reified the image of the Other as an alternative. Nonetheless, this approach has obscured a number of anthropologically pertinent phenomena that I intend to address in the present study.

The first question that was ignored by this abovementioned culturalist view of kinship is that if individual communities and cultures are born because of cultural contacts and are not necessarily systemic/organized, then how should they be understood and described? In my study, I argue that individual communities should not be viewed as insular, isolated from each other. This is true not only of the cultural systems governing kinship but also of the way in which members of the local community regulate the possibilities and interactions of the anthropologist seeking to research kinship.

This paper discusses the dilemmas that emerged during my fieldwork in me and the members of the village communities in Yakutia while studying kinship. These dilemmas

\footnotetext{
${ }^{3}$ Of the many research works on kinship, I must highlight two. During her research among the Chimbu, Paula Brown described the incompatibility of agnatic kinship and patrilineal clans (BROwN 1962), but similar conclusions were drawn by other researchers, too (BARNES 1962; MEGGITT 1965; STRATHERN 1968). In addition to calling into question the anthropological approach that crystallized during the anthropological description of African societies and which viewed the examination of social systems and the kinship relations that created them as inseparable, Roy Wagner also attempted to reconcile local religious ideas with the seemingly loose kinship relations that can be observed in local communities (WAGNER 1967).

${ }^{4}$ Here, the work of David Schneider was a major turning point. He interpreted social phenomena (and thus kinship, too) as a system of behavioral rules categorized and regulated by the cultural system, in which descent or consanguinity is not a fact but a cultural scheme that orders forms of behavior according to values that vary from society to society (SCHNEIDER 1967). This idea leads Schneider to dismiss the research of social typologies. Instead, he argues, it is more useful to examine in each culture the category of kinship, instead of assuming a general and universal phenomenon (SCHNEIDER 1976).

${ }^{5}$ For a critique of this kind of perception of culture, see: ABu-Lughod 1991.
} 
became explicit during my stay in Yakutia and were based on the difference between what the local intellectuals and I considered a phenomenon worthy of researching on the subject of kinship. This difference also determined what local intellectuals and leaders regarded as a legitimate research topic for me. In many cases, their firm ideas on the goals and means of research on kinship helped me a lot during fieldwork, but sometimes they regarded my research interest with confusion, at times even with suspicion.

These two coexisting views are embedded in the context of the locals' perspective on kinship. The locals' kinship perspective not only creates the framework of interpretation within which they assigned my place in the community (and positioned me during the interviews), but also determined what they found suitable of sharing with me, an outsider. ${ }^{6}$ The phenomenon of kinship is typically a topic that neither the researcher nor the locals can view merely analytically, but rather as an integral part of their lives. However, which relationships are considered kinship relations may be highly divergent between researchers and the native community.

During my stay in the field in Yakutia, the interplay of three interrelated perspectives on kinship provided a meaningful frame for my research.

1. My analytical questions about kinship, which were based, on the one hand, on my personal interest and my own personal experiences on the significance of kin relationships, and on the other hand, the insights of anthropological kinship studies I was familiar with.

2. The analytical and non-analytical perspective of the researched community's local historians, ethnographers, museologists, and history teachers on kinship.

3. The opinions of community members about what kinship means to them and what they can share about their relatives with an outsider.

My study - based on the experiences of my subsequent fieldworks in Yakutia (Northeast Siberia) between 2002 and 2013 - provides an example of how anthropological fieldwork can be conducted on the subject of kinship within the network of these three aspects. It is important to note that I do not regard these aspects as perspectives that exclusively define a group of individuals. They are rather abstract points of view that very rarely emerge in the field purely, on their own. Just like I, local intellectuals do not regard all phenomena related to kinship analytically. Furthermore, our long-term coexistence has also resulted in my close friends (many of the local intellectuals among them) being partially embedded in my (formerly seemingly foreign) research perspective. In the remainder of the study, I argue that these three aspects do not correspond with etic and emic criteria. They are hypothetical points of view that can be adopted concurrently, and in which, in a given situation, individuals can be placed between the two.

It is in the framework of these three aspects that I try to retrospectively and critically (re)interpret the role of the anthropologist I played in some of the village communities in Yakutia during (and partly after) my fieldwork. ${ }^{7}$ I do not think that any one of the three

\footnotetext{
${ }^{6}$ It is important to note that at both fieldwork sites, the locals, local intellectuals, and I had a very similar understanding of kinship at that time. Basically, we considered the totality of consanguineal and affinial relationships as the focal subject of interest in kinship.

${ }^{7}$ By correspondence, telephone and Facebook contacts.
} 
viewpoints outlined above can suppress or suspend the other two. That is, neither the researcher's perspective nor the local intelligentsia's viewpoint or the locals' opinions about the targets and means of research work remain immune to each other in the course of an extended fieldwork. The everyday polyphony of different perspectives forces the participants of the fieldwork (anthropologists and locals alike) to suspend their own standpoints temporarily and partially. In other words, to adapt to each other in order to create a common agora for communication in which they can engage in meaningful dialogue with each other.

\section{PARALLEL FIELDWORK AND INTEREST IN KINSHIP}

The mediating role of the local intelligentsia has so far been examined in domestic and international literature only marginally. ${ }^{8}$ However, the role of rural teachers, museologists, and local historians in Russia cannot be emphasized enough. Even Yakutia, one of the most remote, most isolated republics of the Russian Federation, has schools, museums, cultural centers and libraries in nearly every village. As a result, even in the smallest deadend villages (sometimes of less than two to three hundred people), the locals have a clear idea of the significance of ethnography and what an ethnographer might be interested in. This background knowledge has a significant influence on what the villagers deem worthy of mentioning or emphasizing to the anthropologist during the fieldwork.

This is especially true in the case of examining kinship, because in Yakutia, many villagers are not only living and using their kin relationships in everyday life but also looking at them analytically. Kinship is interpreted as a research subject that is important to learn about on an individual level. This means that in the villages I visited, many had written memoirs, kept family records, drew family trees, and created computer databases about their ancestors. ${ }^{9}$ The fact that the anthropologist cannot be regarded as the only fieldworker in the village researching kinship because those he studies have themselves already carried out their own investigations on this subject has had a significant impact on the fieldwork.

I conducted fieldwork mainly on two sites in Yakutia between 2002 and 2012. In order to name these settlements, I use the pseudonyms Tarbaga and Külümnüür. Tarbaga is a settlement in Central Yakutia inhabited almost entirely by Sakhas, and Külümnüür is located in the eastern part of Yakutia, in the Ust-Maysky District. Two thirds of the population of Külümnüür is Evenki, one third Sakha. Both villages have a museum and a school. These all-inclusive museums can be considered local history collections, village archives, and local art galleries at once. Above all, however, both museums have a large genealogical database that processes the history of local lineages and families.

Most of the village intellectuals who create genealogies are not merely amateur, selftaught collectors but qualified ethnographers whose views and research perspectives are rooted in the same international anthropological/ethnographic tradition as mine. Thanks to the local intellectuals educated in Yakutsk and Leningrad, many villagers were aware

\footnotetext{
${ }^{8}$ However, some anthropological works clearly point out the role played by the local intelligentsia in Russia and the role that state institutions play in creating local ethnographic knowledge. ANDERSON 2005; HABECK 2014; NAGY 2016.

${ }^{9}$ For the significance of these written sources, see: MészÁros 2007.
} 


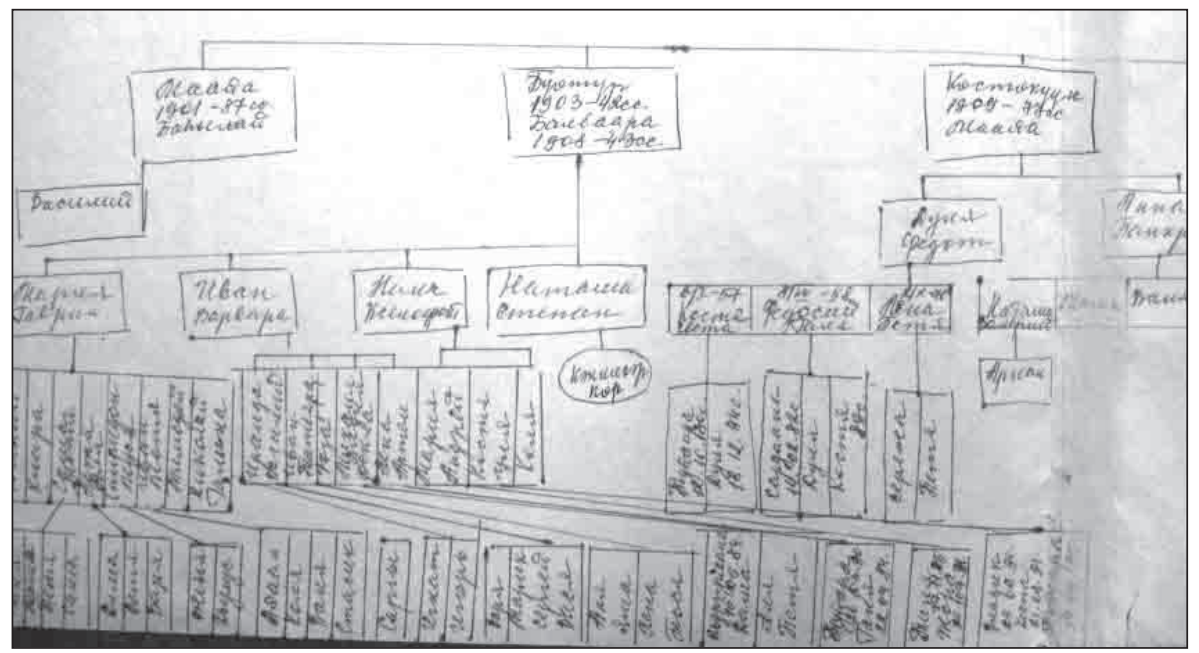

Figure 1. Hand-drawn family tree from the collection of the museum in Tarbaga.

of what ethnographic works were written by ethnographers who previously worked in the area. In Tarbaga, a political exile (Lev Grigorevich Levental) who lived in the area for one and a half decades (between 1884 and 1898) has been preserved in local memory. The exiled Levental not only lived near the village but also opened a school to educate the local poor. A photocopied version of his work on Sakha property relations, which has been collected by Levental mostly in Tarbaga, is kept in the local museum (LeVENTAL 1929).

The situation was the same in Külümnüür, where the local librarian, upon learning that I was also interested in researching kin relationships in their village, handed me at our first meeting Sergei Nikolaev's ethnographic monograph, asserting that this volume contains the most important data (NiKolaev 1964). Aside from Nikolaev's work, locals often compared me to a Spanish ethnographer, Carmen Arnau Muro, who visited the village for a week in 2002. The degree of awareness of ethnographic research is also indicated by the fact that the head of the museum in Külümnüur asked me to acquire the ethnographic work of Viktor Nikolaevich Vasilev (VAsILEv 1930) who conducted fieldwork here in the 1920s. I later sent him this thin volume in a photocopied version from Yakutsk.

The activities of museums and schools in these settlements are concerned not only with collecting and systematizing ethnographic data but also with transmitting the local ethnographic and historical knowledge amassed in these institutions to the locals. The most common form of this is that museum staff are involved in school education, study groups, and tutoring.

In addition, these museums have a special responsibility for supervising local students for educational competitions, as the local pupils usually apply for regional and national competitions with local research topics. The children preparing for the competitions are not only getting assistance from their relatives in collecting the material and preparing the proposal but are also tutored by one of the staff members of the museum. At the 


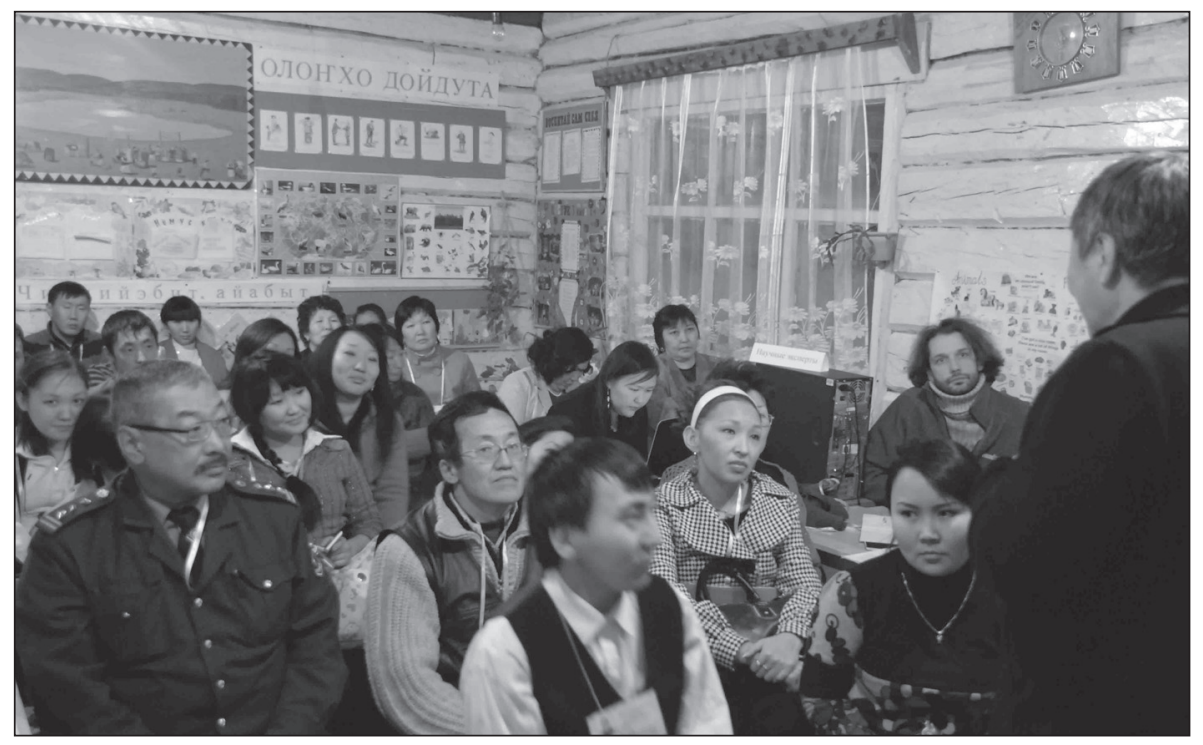

Figure 2. The ethnographic and local history section of a local conference. Aryktaakh, Yakutia, 2009. (Photo by Yuri Slepcov)

nationwide educational competition called "Step into the Future", ${ }^{10}$ all the villages I knew were represented by children wanting to present ethnographic topics. In 2002 in Tarbaga, for example, I assisted in the preparation of an $11^{\text {th }}$ grade student's work (which dealt with the construction history of the local church). The then 17-year-old boy returned to Tarbaga in 2008, shortly after graduating from the History Department of the Yakutsk State University, and he worked as the director of the museum for three years. During my later fieldwork, I regularly contributed to the tutoring of students for the educational competition, and from 2009 onwards, I have even been listed on a few occasions as a supervisor. Participants of educational competitions regularly engaged in local scientific conferences that had ethnographic and local history sections. I myself participated in the work of such sessions as a member of the jury.

Thus, during my fieldwork, I had to face not only the fact that other local ethnographic fieldworks have taken place in my host villages before my research activities but also that parallel ethnographic studies were being conducted during my stay there. Naturally, this also affected how the locals evaluated my fieldwork. The same kind of work was expected of me, too (only at a higher level), as what their children and their tutors were doing when writing their treatises. However, in terms of researching kinship, this proved to be difficult because the methods of the local intellectuals and of Russian ethnographic scholarship differed significantly from what I was trying to do in the field as a researcher.

${ }^{10}$ The website of the competition is available here: http://www.step-into-the-future.ru/ (accessed December 6, 2018) 


\section{VERTICAL AND HORIZONTAL ASPECTS OF KINSHIP RESEARCH}

Russian ethnography, and within that kinship research, is still largely based on the methods and approaches that leading scholars developed in the Soviet era. Kinship studies occupied a central position not only in Anglo-Saxon anthropology but also in Soviet ethnography. After all, this research topic was directly related to the issue of the transformation of family forms and the formation of class societies (ToLsTov 1946). In Soviet ethnography, therefore, kinship research was primarily relevant in the description of certain levels of social development and was thus essentially historical in orientation. Accordingly, in Siberia, kinship research was contingent upon the general research topic related to the development of primeval societies into tribal and clan societies (PERshitz 1980).

For the above reasons, Russian and Soviet ethnography relied heavily on Morgan's works on kinship and the evolution of ancient society (MORGAN 1961). Morgan's view of society and kinship, as mediated by Engels to Soviet ethnography (ENGELS 1975), fit the ideology through which the Soviet state wanted to consider and handle its own minorities. Consequently, Morgan was given a prominent role in Soviet ethnography. He and his work garnered tremendous prestige (ZNAMENSKI 1995). This prestige was so significant that any further kinship theory research was interpreted by Soviet ethnography in relation to Morgan's model of social development (DzIEBEL 2007:99). All this, however, was not just a theoretical-methodological issue.

In Soviet ethnographic research on the Sakha, Morgan's approach manifested in the understanding of the development of tribal/clan society becoming the sole purpose of kinship research. According to this approach, among the Sakha (who in Morgan's nomenclature were in the late stage of barbarism), it was the tribal/clan structure that created the social inequalities and forms of exploitation that the Soviet system abolished (RASCVETAEV 1932). Ethnographic research in Yakutia in the period of repression preceding the Second World War almost completely lacked fieldwork. Why would it be needed? After all, the Soviet economic and social system sought to eliminate exactly those traditional Sakha social formations (i.e., the hidden forms of exploitation) which were based on kin relations.

Sergei Aleksandrovich Tokarev (1899-1985), one of the most important figures of Soviet ethnography, based his research on the social organization of the Sakha exclusively on $17^{\text {th }}$ - and $18^{\text {th }}$-century archival sources (ToKAREV 1945). Tokarev, in the absence of fieldwork, defined authentic Sakha culture in a way that archival sources would be sufficient for its exploration. Thus, to Tokarev, authenticity had meant the assumed characteristics before contact with the Russians. Although defining authenticity in this way was an entirely general anthropological process of creating a colonial Other, the Soviet Union never considered itself a colonial empire. In the context of traditional Sakha culture, they studied what "survival" remnants (perezhitky) of this culture might be found in archival sources or in the works of late $19^{\text {th }}$-century exiles. The purpose of research was to designate the place of $17^{\text {th }}$-century Sakhas in the general developmental model of human societies with the help of an approach that viewed the description and explanation of cultural and social phenomena as related to the examination of the historicity and origins of the phenomena. Ethnographic research had become an understanding of the historicity of ethnographic phenomena and of certain stages of ethnogenesis (TOKAREv 1950). In the Soviet ethnographic research of the time, therefore, 
"the historical ethnographic monograph gradually became the basic form of general ethnographic works" (Tolazlov 1949:24).

Tokarev and his circle had a significant impact on ethnographic research in Yakutia and consequently on the research of kinship as well. The research methodology that the exiled researchers followed (perforce) before the birth of the Soviet system, which required long-term fieldwork, was abolished, and ethnographic research came to instead rely on the exploration of archival resources and short-term extensive ethnographic expeditions. The persistence of this research tradition is also indicated by the fact that none of the nine scientific projects currently underway at the Yakutsk-based "Institute for Humanities Research and Indigenous Studies of the North" require long-term fieldwork. ${ }^{11}$

In the research of kinship (as in other subjects), this particularly Soviet historical orientation has developed an extensive fieldwork technique, mainly typical for the Soviet Union, which still prevails in Russia and in most of its successor states. This fieldwork method significantly deviated from the fieldwork techniques of contemporary Western anthropological research. Soviet ethnographic expeditions, which were conducted mainly in the summer, sought to cover as large an area as possible during collection, dedicating only a short time to the research of a specific settlement. In the settlements investigated, the collectors focused on highly knowledgeable key informants - that is, Soviet ethnographers used not their eyes but rather their ears during fieldwork. As a result, interviewing and interviews were over-represented in the fieldwork in comparison to observation.

This recording, collecting, data-oriented method reminded me of the first major collective anthropological fieldwork in the Torres Islands (Dragadze 1971) - and it was far from the loneliness of a long-term stationed fieldwork which, after Malinowski, considered participant observation a central information-acquiring process. I do not, however, claim that Russian ethnology is wrong. I believe that the researchers in Yakutia use different ways to achieve different results, from which a different kind of ethnographic knowledge is built.

Being familiar with the methodology and the approach of Yakutian ethnographic research, the teachers, museologists, and local historians working in Tarbaga and Külümnüür not only helped and interpreted but also influenced my fieldwork. My interests and methods did not fit into the image they had of a truly professional researcher. Three specific features of my fieldwork have caused confusion among the intellectuals dealing with ethnographic issues in the village.

1. Why am I staying in the village for so long? How does this help my work?

2. Why am I asking certain people about the topic of kinship when others are more knowledgeable?

3. Why is it important to inquire about today's conditions in the village when past events are much more interesting?

During my stay in the villages, I was already aware that this difference in parallel perspectives was partly due to the differences between the ethnography of the Soviet Union (and later Russia) and the Anglo-Saxon anthropological tradition. In the villages,

${ }^{11}$ http://www.igi.ysn.ru/index.php?page=nauchnaya (accessed October 6, 2016) 
however, I was primarily concerned with how I could understand the locals and how we could create a common framework within which we would be able to interpret each other's actions and utterances. As a result, I was not inclined to understand more deeply which scientific tradition would the approach to kinship studies that the local ethnographers working in the villages advocated fit into.

Now, however, when interpreting the circumstances of my fieldwork in retrospect, it is worth comparing these differing approaches. What could be said of my own interests has already been said in my book published in 2013. I tried to interpret the phenomenon of kinship in juxtaposition with neighborly and friendly relations in the context of local power relations (MÉsŹ́́ros 2013). This interpretation fits well into the discourse describing post-Soviet societies, which seeks to examine the role and functioning of network resources in societies with a weak civil society and limited bridging social capital. Accordingly, I focused primarily on horizontal relationships, that is, the quantity and quality of social capital available at a given time.

By contrast, local researchers were interested in the vertical features of kinship. First and foremost, they sought to reconstruct the ascending lineages of kinship groups as precisely as possible (and at the same time permanently overriding inconsistent alternative narratives preserved in oral tradition and local memory). A list of ancestors is important not only to ethnographers; for Sakhas, it is also important to create genealogical records about agnatic lineages. Therefore, in Tarbaga and Külümnüür, not only local historians and ethnographers created genealogies. In many villages of Yakutia, the narrative recording of the past and of ancestors has a significant tradition. However, the kind of reconstruction that characterizes the activities of local ethnographers does not correspond to the local approaches to history and kinship (which lacks the analytical aspects of ethnography) which have been preserved in the prose narratives of the local oral tradition. ${ }^{12}$ The question then is how this local ethnographic interest focused on genealogies and kinship can be placed in the history of international anthropology.

In the research of kinship, the pursuit of ascending lineages and their recording in a single authentic form (and discrediting contentious genealogies at the same time) was common during a specific period of anthropological research. In his 1871 work, "The Descent of Man, and Selection in Relation to Sex", Charles Darwin was the first to argue in detail that man was also part of the selection process. The theory of evolution, in addition to interpreting the previously culturally interpreted genealogical relations as a natural phenomenon, also made it clear that the properties of ascending lineages leave their mark on the descendants in an irrefutable and indelible way (ZERUBAVEL 2012:39-41). While previously it was mainly structural similarities and correspondences that determined the sociological interpretation of nature and human culture, now the idea of a common origin and ancestry has become more and more dominant. Origin and pedigree have become decisive issues in certain cultural phenomena, and especially so in views on kinship and social organization (KeNDALL 1888).

At the time when anthropological research was developing and when the first fieldwork considered to be anthropological was being conducted, this genealogical approach was one of the dominant theories that experts used to interpret cultural phenomena. William

${ }^{12}$ I described the differences between the two approaches to the past and kinship in detail when comparing family histories and genealogies: Mészáros 2007. 
Halse Rivers, who turned genealogical research into a method, played an important role in the history of anthropology not only as a theoretician of kinship research but also as the organizer and participant of the first serious anthropological expedition to the Torres Islands. The genealogical method developed by Rivers (and perfected in the course of successive fieldworks) has been the first attempt at developing a process independent of culture that makes a community's knowledge of kinship available in making comparisons..$^{13} \mathrm{~A}$ particular feature of this method is that it was not developed by Rivers in an armchair but in the field, and therefore it includes the approach to kinship of the Vella Lavella community he studied in the Torres Islands (Berg 2014:110). During his research among the Todas in South India, Rivers further refined the method, and sought to capture the totality of social life primarily through setting up genealogies. For this reason, in his writing on the Todas, Rivers paid little attention to behavioral rules (a total of three pages in his 1906 monograph) (RIVERs 1906:498-501).

Thus, Rivers' genealogical method is very similar to the method used by local ethnographers today in Yakutia. Moreover, by expanding Rivers' method, they focus not only on the research of local communities but also on the complex societies of larger political entities. In 2014, an independent fiscal institution was established in Yakutia for setting up the family tree of Yakutia's entire indigenous population. The institute, called "The Institute for the Genealogy and Ethnology of the Northern Nations of Yakutia", seeks not only to create an online electronic genealogical database of the entire republic, but also to train specialists who, using genealogical methods, would map the ancestors of locals in certain settlements of Yakutia. ${ }^{14}$ By the end of 2015, the institute's staff were able to set up a family tree system covering 18,000 people (in some cases going back two generations, in others thirteen generations). The institute is supported not only by the government of the Sakha Republic but, through volunteers and data, the local governments of each municipality as well. The first publications of this grandiose research have already been printed, foreshadowing a detailed genealogical chart which, treating kinship statically, creates a single legitimate genealogy system.

Based on this, I believe that the activities of local ethnographers can be integrated into an epistemological and methodological tradition (in which Morgan's and Rivers' works are particularly determinative) that is ultimately part of the same anthropological knowledge in which I myself am working. In other words, the local ethnographers are not accumulating knowledge that is qualitatively different than mine, but one that is based on a different approach to kinship.

${ }^{13}$ It is important to note here that this is exactly the procedure that David Schneider criticized. Rivers is only applying the ideas he formed of his own (i.e., English) kinship to the Todas, thus he only understands what kinship means among the Todas based on consanguineal relationships (SCHNEIDER 1972:54).

${ }^{14}$ For a brief description of the research and the institute: http:/grants.oprf.ru/grants2014-3/zhurnal/ rec337/?order=DESC (accessed December 6, 2018) 


\section{AN ETHNOGRAPHER-ANTHROPOLOGIST IN SIBERIA}

My activity in Yakutia as an ethnographer (compared to the anthropological conduct I had previously imagined) provided me with different kinds of rules of conduct and roles in Siberia than I had expected. In the first few weeks of fieldwork, I wondered what to do with the expectations of the local intellectuals in Tarbaga (and the set role they implied). I think that participating in mutual language-game means not only understanding each other's goals, motivations, and utterances but also the effective implementation of related actions in the course of the language-game. For this reason, I not only had to reflect upon the role of ethnographer assigned to me, I had to (at least partially) fulfil it, too. In Tarbaga and Külümnüür, this specifically meant that I had to perform ethnographic research tasks that were originally not part of my envisioned anthropological fieldwork. I did all this so that my presence would be interpretable and meaningful to the locals as well. In the closing paragraphs, I try to describe how I worked as a Yakutian ethnographer in the field in addition to conducting anthropological fieldwork.

In Russia, ethnographers - especially those working in small settlements and who, besides doing ethnographic research, also fulfil the role of local historian, librarian, or cultural center manager - have other tasks besides research. Therefore, the moment I as an anthropologist stepped into my role in the community as an ethnographer, I was suddenly assigned a host of tasks that usually, in other situations, would rarely be assigned to a researcher. However, as I felt that an important part of learning and jointly developing the mutual language-game was to converge my own activities with my local ethnographer's role, I decided to fulfil these tasks according to my abilities and capacities. Neither then, nor later did I think that this would be interfering in the life of an intact community. I knew I would get some role in the community, and I also knew that my presence could not be ignored from an epistemological point of view.

My role as ethnographer primarily included teaching, seeing that the majority of local ethnographers work in rural schools. Because of this, besides supervising talented pupils for educational competitions, I regularly taught at local schools in both villages (I taught English and national culture). In addition, I held a summer camp for children and attended school expeditions. An important task of ethnographers in Russia is to provide decision-making bodies with expertize and opinions (FunK 2016). In 2013, I wrote a report on the teaching of humanities in the school in Tarbaga to the head of the regional educational department (an ethnographer-historian himself), arguing that turning the school into an agricultural vocational school is not expedient because it provides a high-quality education in the humanities. ${ }^{15}$ In Külümnüür, the head of the village asked me to report to him, after finishing my fieldwork, on the difficulties I saw in the village as an ethnographer and the solutions I would propose for them. I even signed an official, jointly sealed agreement of cooperation with the leadership of the village.

In addition to assisting in the schools, I also participated in the work of the local museums in both settlements. In the museum of Tarbaga, I digitized handwritten family histories and hand-sketched family trees, and in Külümnüür, where there was no genealogical chart covering the entire population of the village, we created one with

${ }^{15}$ In spite of all this, the school in Tarbaga was transformed in 2013 by regional management into a school that provided agricultural vocational training as well. 
Ljubov Innokentivna Sedailsheva, the local history teacher. After four weeks of work, using the method that William Halse Rivers introduced in anthropological research, the local art teacher and I plotted the family tree and kin relationships of the people of the village on huge sheets of papers. Unfortunately, I could not stay in Külümnüür to see these charts colored by schoolchildren and displayed on the walls of the museum, but the exhibition called "Urukku agha uustar, anygy ud'uordar", or "Ancient Lineages, Present Descendants", was already fully prepared with the staff of the museum. I could continue listing all the other activities with which I contributed to the work of the local schools and local museums, but these few examples shall suffice to illustrate the way in which I considered my fieldwork in the Yakutian villages authentic and meaningful.

I do not think a researcher can avoid intervening in a community's life. This is especially inconceivable to me when one stays there for extended periods of time and keeps going back to visit his friends. However, since there is no way to avoid the effect of the researcher's (and human being's) presence on the community, it may be right to reflect upon it and participate in the life of the community in a way that seems meaningful to both the locals and the researcher. There are no rules for what role a researcher shall play in a community and how he shall fulfil that role. Everyone makes mistakes and stumbles sometimes during fieldwork. But the more reflective the presence of the researcher and the more it can be interpreted by the locals, the greater the chance that the anthropologist will remain authentic throughout the fieldwork, both from the human and the research point of view. When the man - and the researcher - is welcomed back by the locals, it is perhaps a substantial indication that he did not make too many mistakes in his fieldwork.

\section{REFERENCES CITED}

ABu-Lughod, Lila

1991 Writing against Culture. In Fox, Richard G. (ed.) Recapturing Anthropology: Working in the Present, 137-162. Santa Fe: School of American Research Press.

Anderson, David G.

2005 Bringing Civil Society to an Uncivilised Place: Citizenship Regimes in Russia's Arctic Frontier. In Hann, Chris - Dunn, Elizabeth (eds.) Civil Society

BARNES, J. A.

Challenging Western Models, 97-119. London, Routledge.

1962 African Models in the New Guinea Highlands. Man 62:5-9.

Berg, Cato

2014 The Genealogical Method. Vella Lavelle Reconsidered. In HvidING, Edvard - Berg, Cato (eds.) The Ethnographic Experiment: A.M. Hocart and W.H.R. Rivers in Island Melanesia 1908, 108-132. New York: Berghahn Books.

Brown, Paula

1962 Non-agnates among the Patrilineal Chimbu. Journal of the Polynesian Society 71:57-69.

DRAGADZE, Tamara

1978 Anthropological Fieldwork in the USSR. Journal of the Anthropological Society of Oxford 9:61-70. 
DzIEBEL, German Valentinovich

2007 The Genius of Kinship. The Phenomenon of Human Kinship and the Global Diversity of Kinship Terminologies. New York: Cambria Press.

ENGELS, Friedrich

1975 A család, a magántulajdon és az állam eredete [The Origin of the Family, Private Property, and the State]. Budapest: Kossuth.

FunK, Dmitri Anatolievich

2016 "Néprajzi szakértés" a posztszovjet Oroszországban ["Ethnographic Expertize" in Post-Soviet Russia]. Ethnographia 127(3):345-368.

Goodale, Jane

1971 Tiwi Wives. Seattle: University of Washington Press - American Ethnological Society.

HABECK, Joachim Otto

2014 Das Kulturhaus in Russland: Postsozialistische Kulturarbeit zwischen Ideal und Verwahrlosung [The House of Culture in Russia: Post-Socialist Cultural Work between Ideal and Decay]. Bielefeld: Transcript Verlag.

Kendall, Henry

1888 The Kinship of Men: An Argument from Pedigrees, or Genealogy Viewed as a Science. Boston: Cupples and Hurd.

LEVENTAL, Lev Grigorevich

1929 Podaty, povinnosti i zemlja u jakutov [Taxes, Duties and Land among the Yakut]. In Majnov, I. I. (ed.) Materialy po obychnomu pravu i obshchestvennomu bytu jakutov [Materials on the Customary Law and Social Life of the Yakuts]. Leningrad: Akademii Nauk.

MARSHALl, Lorna

1976 The !Kung of Nyae Nyae. Cambridge: Harvard University Press.

MegGitt, M. J.

1965 The Lineage System of the Mae-enga. Edinburgh: Oliver and Boyd.

MÉszÁros, Csaba

2007 Az ágazati mondáktól a családtörténetekig és a memoárokig. Az írásbeliség hatása a múltszemléletre Jakutiában [From Legends of Lineage History to Family Histories and Memoires. The Effects of Literacy on Approaches to the Past in Yakutia]. In Szemerkényi, Ágnes (ed.) Folklór és történelem, 44-70. Budapest: Akadémiai Kiadó.

Morgan, Lewis Henry

1961 Az ösi társadalom [Ancient Society]. Budapest: Gondolat.

NAGY, Zoltán

2016 Osztjákok vagy hantik? Diskurzusok között vergődve [Ostyak or Khanty? Inbetween Discourses]. Ethnographia 127(3):369-390.

NikolaEv, Sergei Ivanovich

1964 Eveni i Evenki jugo-vostochnoj Jakutii [Evens and Evenks of Southeastern Yakutia]. Yakutsk: Bichik.

PATTERSON, Mary

2005 Introduction: Reclaiming Paradigms Lost. The Australian Journal of Anthropology 16(1):1-17.

Pershitz Abram I. 
1980 Ethnographic Reconstruction of the History of "Primitive Society". In Gellner, Ernest (ed.) Soviet and Western Anthropology, 85-94. New York: Columbia University Press.

Rascvetaev, M. K.

1932 Ocherki po ekonomii $i$ obshchestvennomu bytu $u$ jakutov [Essays on the Economy and Social Life of the Yakuts]. Leningrad: Izdatelstvo Akademii Nauk SSSR.

RIVERS, William Halse

1906 The Todas. London: MacMillan and Co.

SCHNEIDER, David

1967 Kinship and Culture: Descent and Filiation as Cultural Constructs. Southwestern Journal of Anthropology 23:65-73.

1969 Some Muddles in the Models: or, how the System Really Works. In BANTON, Michael (ed.) The Relevance of Models for Social Anthropology [ASA Monographs 1], 25-86. London: Tavistock Publications.

1972 What is Kinship All About? In ReInIng, Priscilla (ed.) Kinship Studies in the Morgan Centennial Year, 32-63. Washington, D.C.: The Anthropological Society of Washington.

1984 A Critique of the Study of Kinship. Ann Arbor: University of Michigan Press. STRATHERn, Andrew

1968 Descent and Alliance in the New Guinea Highlands: Some Problems of Comparison. Proceedings of the Royal Anthropological Institute for 1968, 37-53.

ToKarev, Sergei A.

1945 Obshchestvennyj stroj jakutov $v$ XVII-XVIII vv [The Social Structure of the Yakuts in the $17^{\text {th }}-18^{\text {th }}$ Centuries]. Yakutsk: Yakutskoe Knizhnoe Izdatelstvo.

1950 Az ethnogenezis problémája [The Problem of Ethnogenesis]. Ethnographia 61:1-28.

Tolazlov, S. P.

1949 A szovjet etnográfiai iskola [The Soviet Ethnographic School]. Ethnographia $60: 24-45$.

Tolstov, C. P.

1946 K voprosu o periodizacii pervobitnogo obshchestva [On the Question of the Periodization of Primitive Society]. Sovetskaja Etnografija 1:3-15.

VAsILEV, Viktor Nikolaevich

1930 Predvaritelnij otchet o rabotah sredi Aldano-Majskih $i$ Ajano-Ohotskih tungusov [Preliminary Report on the Work among the Aldan-Maysky and Ayano-Okhotsky Tungus]. (Materialy komissii po izucheniju JaASSR. Vyp. 36.) Leningrad: k.n.

WAGNER, Roy

1967 The Curse of Souw? Principles of Daribi Clan Definition and Alliance in New Guinea. Chicago - London: The University of Chicago Press.

Zerubavel, Eviatar

2012 Ancestors and relatives. Genealogy, Identity, and Community. Oxford: Oxford University Press.

ZnAMENSKI, Andrei A. 
1995 A Household God in a Socialist World. Lewis Henry Morgan and Russian/ Soviet Anthropology. Ethnologia Europaea 25:177-188.

Csaba Mészáros is a research fellow at the Institute of Ethnology in the Research Centre for the Humanities at the Hungarian Academy of Sciences. He works in the department of social anthropology and has been involved in a number of domestic and international research projects in Siberia and the Carpathian Basin. His interests cover a wide range of topics, from ecological anthropology to kinship studies. This article is the result of his current research project on kinship, sponsored by the Bolyai State Research Fund. E-mail: meszaros.csaba@btk.mta.hu 